\title{
REWARDS VERSUS INTELLECTUAL PROPERTY RIGHTS
}

\author{
Steven Shavell \\ Tanguy van Ypersele \\ Working Paper 6956 \\ http://www.nber.org/papers/w6956
}

\section{NATIONAL BUREAU OF ECONOMIC RESEARCH 1050 Massachusetts Avenue \\ Cambridge, MA 02138 \\ February 1999}

The views expressed here are those of the author and do not reflect those of the National Bureau of Economic Research.

(c) 1999 by Steven Shavell and Tanguy van Ypersele. All rights reserved. Short sections of text, not to exceed two paragraphs, may be quoted without explicit permission provided that full credit, including ${ }^{(0)}$ notice, is given to the source. 
Rewards versus Intellectual Property Rights

Steven Shavell and Tanguy van Ypersele

NBER Working Paper No. 6956

February 1999

JEL No. D23, K11, L10

\section{ABSTRACT}

This paper compares reward systems to intellectual property rights (patents and copyrights). Under a reward system, innovators are paid for innovations directly by government (possibly on the basis of sales), and innovations pass immediately into the public domain. Thus, reward systems engender incentives to innovate without creating the monopoly power of intellectual property rights, but a principal difficulty with rewards is the information required for their determination. We conclude in our model that intellectual property rights do not possess a fundamental social advantage over reward systems, and that an optional reward system - under which innovators choose between rewards and intellectual property rights - is superior to intellectual property rights.

\section{Steven Shavell}

Harvard Law School

1575 Massachusetts Avenue

Hauser Hall 508

Cambridge, MA 02138

and NBER

shavell@law.harvard.edu

Tanguy van Ypersele

Department of Economics

Tilburg University

P.O. Box 90153

NL-5000 LE Tilburg

The Netherlands

tanguy@kub.nl 


\title{
Rewards versus Intellectual Property Rights
}

\author{
Steven Shavell and Tanguy van Ypersele*
}

\section{Introduction}

Two basic means of stimulating innovative activity are compared in this paper. One is a system of rewards paid by the government to innovators. According to this system, innovations would pass immediately into the public domain, becoming freely available to all. The other approach is the familiar system of intellectual property rights that we employ, notably, patent and copyright protection, under which the government confers to innovators exclusive rights to market the goods and services that embody their intellectual works.

Our main conclusion is that the intellectual property rights system does not enjoy any fundamental advantage over the reward system. Indeed, an optional reward system — under which an innovator can choose between a reward and intellectual property rights - is superior to the intellectual property rights system in the model we examine. These findings derive from the primary virtues of reward systems: that incentives to innovate are provided without granting innovators monopoly power over price; and that the magnitude of research incentives may be selected by government. A principal difficulty with reward systems, however, concerns the government's need for information to calculate rewards (although the government might be able

\footnotetext{
*Harvard Law School and the National Bureau of Economic Research; and the Department of Economics, Tilburg University, the Netherlands, respectively. Shavell acknowledges research support from the John M. Olin Center for Law, Economics, and Business at Harvard Law School; van Ypersele acknowledges research support from the Belgian American Educational Foundation and the Catholic University of Louvain (UCL). We are grateful to Illoong Kwon for research assistance and to Louis Kaplow, Steven Levitt, F. M. Scherer, and Suzanne Scotchmer for comments on the paper.
} 
to base rewards on sales volume).

To motivate our analysis, we first mention a significant historical episode about the patent system and rewards. Although a fairly well-developed patent system had emerged as early as the 1400 's in Venice and had spread through much of Europe and the New World by the end of the $18^{\text {th }}$ century, the system came under strong attack in the next century, especially during the period $1850-1875 .^{1}$ Criticism of the patent system reflected dislike of monopoly power, both because it harms consumers who have to pay high prices and because it can hinder improvements and subsequent innovations if patent holders disallow that. ${ }^{2}$ Many economists disapproved the patent system, and in some countries, such as Germany, the economics profession was virtually unanimous in its opposition to patent. $^{3}$

Reward systems were widely discussed as an alternative method of spurring innovation (and they had been used to a not inconsiderable extent ${ }^{4}$ ). For example, Robert Macfie, a member of Parliament in England and an influential champion of rewards, set out a proposal for a government-financed reward system to replace patent, the London Economist pressed for

\footnotetext{
${ }^{1}$ On the history of patent, see Dutton (1984), Machlup (1958), MacLeod (1988), and, especially, Prager (1944). For an account of the $19^{\text {th }}$ century European debate about patent, see Machlup and Penrose (1950); and see also Chapter 1 of Dutton (focusing on Britain in the $19^{\text {th }}$ century) and Chapter 10 of MacLeod (focusing on Britain in the $18^{\text {th }}$ century). For materials relating to the patent debate, see Macfie $(1869,1875,1883)$.

${ }^{2}$ Another criticism was that innovators did not actually receive much of the profits from patents because businesses to which they sold their rights made the lion's share; thus, it was argued, patents did not really provide a strong motive to innovate. A quite different criticism was that patents were not needed to induce innovators: on one hand, they could often earn enough to induce innovation merely by being first to market; on the other, they often were motivated by fame and honor, so financial incentives were not necessary. On the criticisms made of patent, see Macfie (1869, 1883) and Machlup and Penrose (1950).

${ }^{3}$ See Macfie (1883 p. 141) and Machlup and Penrose (1950 p. 4).

${ }^{4}$ See MacLeod (1988 pp. 191- 96), who notes that at least eight acts authorizing rewards for specific inventions were passed by Parliament between 1750 and 1825, that substantial sums were granted by Parliament to specific inventors (such as $£ 30,000$ to Edward Jenner for his smallpox vaccine), and that many organizations (especially industry groups) instituted reward schemes.
} 
adoption of a reward system, and economists examined rewards in professional journals, books, pamphlets, and conferences. ${ }^{5}$ Opinion was, however, divided on the virtues of rewards (criticism of patents did not imply endorsement of rewards). The chief argument against rewards concerned difficulties in their administration; it was typically expressed by John Stuart Mill, who maintained that patent is preferable "because it [patent] leaves nothing to anyone's discretion; because the reward conferred by it depends upon the invention's being found useful, and the greater the usefulness, the greater the reward..."6

As a consequence of the criticism of patent, and also of the possible utility of rewards as an alternative, many countries in Europe prepared to reform or abolish patent, and some actually did so: England established a series of royal commissions from the 1850 's to the 1870 's to investigate the patent system; Chancellor Bismarck recommended abolition of patent in Prussia in 1868; Holland repealed its patent system in 1869; Switzerland, which had no patent law, rejected legislation to adopt it in 1863 . Nevertheless, Europe ultimately embraced patent, but for reasons that may perhaps be regarded as more politically accidental than indicative of a substantive policy judgment favoring that system. ${ }^{7}$

In any case, today, intellectual property rights provide the principal legal financial stimulus for innovation. ${ }^{8}$ Rewards are little employed; their payment appears to be limited to inventions in

\footnotetext{
${ }^{5}$ Macfie's proposal is reproduced in Macfie (1869 pp. 84-87). Machlup and Penrose (1950 p. 19) describe the attention given to rewards by the Economist and state that reward proposals "were discussed in the professional journals and conferences almost everywhere."

${ }^{6}$ Mill (1872 p. 563).

${ }^{7}$ See Machlup and Penrose (1950 pp. 3 - 6). They suggest that the victory of patent was associated with the weakening of the free-trade movement (which was occasioned by the economic depression of the 1870s), as the free-trade movement was closely linked politically to the anti-patent forces.

${ }^{8}$ For a description of, and materials on, intellectual property rights protection, see, for example, Goldstein (1993).
} 
the area of atomic energy and to certain other exceptional cases, although they were provided to inventors in the former Soviet Union. ${ }^{9}$

Modern economic literature reflects our reality and takes the general optimality of intellectual property rights largely as a given; the possibility of rewards is paid relatively little attention, despite the history we have summarized, and despite the seeming appeal of the topic to the intellect of the economist. ${ }^{10}$ There have been few papers written in economics journals this century on reward. Two exceptions are Polanvyi (1943) and Wright (1983). Polanvyi recommends, in a sustained and insightful but informal argument, that rewards be adopted to foster innovation and to avoid the social losses associated with patent monopoly power; he offers reasons why informational difficulties facing the government in determining awards should not prove insurmountable. Wright is the first to consider a formal model of innovation in which innovators possess superior information to the government, and he finds that rewards are better than patents if the government's information is sufficiently good. Also, Kremer (1997), in an interesting, related paper, suggests that the government avoid social losses associated with patents by purchasing them at a price that it obtains from an auction process. (Governments have in fact occasionally purchased patents, and proposals for this to be done programmatically have

${ }^{9}$ The United States Atomic Energy Act (1946) established a Patent Compensation Board to grant financial rewards for innovations relating to atomic energy that are of military value (the government does not allow such innovations to be sold on commercial markets). The English patent laws allow for a patent to be infringed upon by the state if it has a "Crown use" for the patented good, in which case compensation, that is, a reward, is to be paid; see Halsbury's Laws of England (1994 pp. 270 - 73). The former Soviet Union made rewards to individual innovators; notably, an innovator might obtain a percentage (on a sliding scale, from $17 \%$ to $.5 \%$, but subject to an absolute ceiling) of the cost savings achieved by a process innovation; see Sinnot (1988 pp. $44-51$ ).

${ }^{10}$ This is not to say that the possibility of rewards is entirely ignored; for example, in his classic essay, Arrow (1971 p. 153) mentions the intrinsic appeal of rewards. However, the lack of importance of rewards in the economic literature is indicated by how little space is devoted to the topic in the chapters on innovation in several well-known books on industrial organization: Scherer (1980 p. 458) spends only a page on rewards; Scherer and Ross (1990), a later edition of Scherer (1980), does not mention rewards; and Tirole (1988 p. 401) discusses rewards in only half of a page. 
sometimes been advanced. ${ }^{11}$ ) Another paper of significance is Scotchmer (1997); although she

does not emphasize rewards, she characterizes the optimal form of patent system assuming that innovators possess superior information to the government. ${ }^{12}$

In this paper, we examine a model in which a single potential innovator knows the demand curve for the product innovation he might produce before he invests in research, whereas the government knows only the probability distribution of demand curves. ${ }^{13}$ We first compare the patent system (for concreteness, we refer to patent rather than to intellectual property rights in general) to the reward system. ${ }^{14}$

Under the patent system, the innovator's incentive to invest in research is the monopoly profits he would earn, and if he produces the innovation, he then sells the innovation at the monopoly price. There are two familiar deviations from first-best behavior under the patent system. First, incentives to invest in research are inadequate, because monopoly profits are less

${ }^{11}$ For example, as Kremer (1997) notes, the French government purchased the patent for the Daguerrotype in 1839. In 1851, a proposal was made in the English Parliament for government to purchase patents routinely; see Macfie (1883 p. 33).

${ }^{12}$ Her main result is that direct revelation mechanisms are equivalent to patent renewal systems — systems in which patentees are able to extend the length of their patents by paying fees (or accepting reduced patent subsidies) for renewals. Such systems have the feature that they implicitly make use of innovators' private information; notably, innovators with more valuable patents will be the ones who will tend to purchase longer patent extensions. In Scotchmer (1998), a revision of her paper, she notes the results on rewards that we demonstrated in an earlier version of this paper, and she solves in certain cases for optimal renewal schemes which incorporate rewards.

${ }^{13}$ However, as we will note, we consider a version of the model in which the government observes quantity sold in the market and makes inferences from that in formulating rewards. As this is the most plausible form of reward system, it is very important for properly interpreting the analysis here to bear it in mind. For further discussion of this issue, see Section IIH and Section III.

${ }^{14}$ The chief contributions of our paper are (a) that it clarifies the comparison between patent and reward through use of a simple and natural model of innovation, and (b) that it investigates the optional reward system and shows it to be superior to patent. 
than the social surplus created by an innovation. ${ }^{15}$ Second, if an innovation results, there is a deadweight loss in social welfare because too little is sold at the monopoly price.

Under the reward system, the innovator's incentive to invest in research is the reward he would receive. If the innovator produces an innovation, it will be available to competitors, so will sell at marginal cost (perfect competition in the product market is assumed). Because there is thus no deadweight loss from monopoly pricing, the only type of deviation from first-best behavior under the reward system involves the incentive to invest in research. This deviation could be in either direction. If the social surplus from the demand curve exceeds the reward, there will be an inadequate incentive to invest, and if the surplus from the demand curve is less than the reward, there will be an excessive incentive to invest. Either possibility may occur, as the optimal reward equals the expected surplus over the distribution of possible demand curves.

From the foregoing, it is apparent that the comparison between the patent and the reward systems can be resolved into two elements. On one hand, the reward system is superior to patent in that deadweight loss due to monopoly pricing is avoided under reward. On the other hand, the incentive to invest in research is imperfect under both systems, but in different ways. Under the patent system, the incentive to invest is always inadequate because monopoly profits are less than social surplus; but the incentive to invest is linked to actual social surplus because the innovator knows the demand for the potential innovation. ${ }^{16}$ Under the reward system, the incentive to invest is governed by the reward and thus is not systematically inadequate; yet the incentive to

\footnotetext{
${ }^{15}$ However, in a model in which there are multiple potential innovators, there could be an excessive incentive to invest in innovation research created by the race to be first. But as we suggest in Section III, taking this point into account would not affect the qualitative nature of our conclusions.

${ }^{16}$ This point is related to Mill's statement above, although he and other critics of reward were concerned not only about government's lack of information but also about abuse of its authority and the rights of inventors.
} 
invest is not linked to actual surplus but only to the reward. ${ }^{17}$ In particular, if the innovation would be very valuable, the innovator would invest only in accordance with the reward, which will equal the expected surplus from all possible innovations.

Because patent effectively harnesses the private information of the innovator about the value of an innovation, incentives to innovate might be superior under patent to those under reward, even though the incentives under patent are always less than first-best. This leads to the possibility that patent could be superior to reward, despite the deadweight loss due to monopoly pricing and the too-small incentive to innovate. Reward, however, could be superior to patent, both because of a better average incentive to innovate (as the optimal reward equals expected surplus) and because of avoidance of the deadweight loss from monopoly pricing. Analysis of patent versus reward does not lead one to think that there exists any general argument favoring the patent system over the reward system.

We next consider the optional reward system, under which an innovator may choose between a patent and a reward. ${ }^{18}$ This system unambiguously dominates patent. The main reason is that we show that (expected) social welfare can be improved when the innovator chooses reward, for deadweight loss is then eliminated, and potential problems with overinvestment in research can be addressed by the government's selecting an appropriately moderate level of reward. Because social welfare is improved relative to patent when the innovator chooses reward, the optional system must be superior to patent, since there is obviously no difference

\footnotetext{
${ }^{17}$ Note, however, that when the reward is conditioned on quantity sold, reward will reflect surplus to the degree that quantity sold does.

${ }^{18}$ Such a system was proposed by Polanvyi (1943). Note too that a system in which the government offers to buy patents is of this type.
} 
between the systems when the innovator chooses patent.

Although the optional reward system is superior to the patent system, and the patent system might be superior to the (mandated) reward system, when the reward system is superior to patent, we show that the reward system might also be superior to the optional reward system.

We then briefly consider the important possibility of rewards that are a function of government's observation of quantity sold in the market. Such quantity-based rewards are obviously superior to the (unconditional) rewards we have been discussing and enhance the appeal of reward systems over patent.

After analysing the patent, reward, and optional reward systems in our model, we discuss briefly a number of issues not considered in the model including: the government's ability to obtain information about demand for the purpose of determining rewards (especially by observation of quantity sold); the race to be first to innovate; improvements to innovations; administrative costs; the financing of rewards through income taxation and possible associated distortionary costs; and the actual potential of reward systems for raising welfare.

\section{The Model}

A risk-neutral (potential) innovator may invest in research which will result in an innovation with a probability that depends positively on the research investment. Let

$\mathrm{k} \quad=$ research investment; $\mathrm{p}(\mathrm{k})=$ probability of an innovation; $\mathrm{p}^{\prime}(\mathrm{k})>0 ; \mathrm{p}^{\prime \prime}(\mathrm{k})<0$.

If there is an innovation, a new product ${ }^{19}$ can be produced at a constant per-unit cost; define

\footnotetext{
${ }^{19}$ Were we to study process innovations (see, for example, Chapter 10 of Tirole (1988)) instead of product innovations, the general nature of our results would not be altered.
} 
c $\quad=$ unit cost of the innovation product.

Regarding the demand curve for the product, let

$\mathrm{q}=$ quantity of the product;

$\mathrm{d}(\mathrm{q} ; \mathrm{t})=$ (inverse) demand curve for the product; $\mathrm{d}_{\mathrm{q}}(\mathrm{q} ; \mathrm{t})<0$;

where

$\mathrm{t}=$ parameter in $\left[\mathrm{t}_{\mathrm{a}}, \mathrm{t}_{\mathrm{b}}\right]$

$\mathrm{g}(\mathrm{t})=$ probability density of $\mathrm{t} ; \mathrm{g}(\mathrm{t})>0$ on $\left[\mathrm{t}_{\mathrm{a}}, \mathrm{t}_{\mathrm{b}}\right]$.

We assume that at $t_{\mathrm{a}}$, monopoly profits, deadweight losses from monopoly pricing, and social surplus (these are described below) are positive, ${ }^{20}$ and that they increase with $\mathrm{t}$.

We suppose that the function $\mathrm{p}(\mathrm{k})$, the cost $\mathrm{c}$, the family of possible demand curves $\mathrm{d}(\mathrm{q} ; \mathrm{t})$, and the density $\mathrm{g}(\mathrm{t})$ are common knowledge for the innovator and the government. The innovator alone knows t. ${ }^{21}$ Also, we suppose until later that the government does not observe quantity sold. (In Section IIH we allow the government to observe quantity and to base the reward on this.)

Social welfare is assumed to be the expected value of the utility individuals obtain from the innovation product, minus production costs, and minus research investment.

\section{A. First-best Outcome}

If there is an innovation, the first-best quantity, denoted $q(t)$, is such that the height of the

\footnotetext{
${ }^{20}$ Thus, we are implicitly supposing that the government's information is good enough to screen out innovations with no value (or with no expected value). This assumption makes sense if the government devotes positive resources to screening innovations, and it is also justified if the government obtains information from sales of innovations, as discussed in Section IIH and Section III.

${ }^{21}$ The assumption that the innovator has perfect information about demand (since he knows $\mathrm{t}$ ) and that the government does not is the simplest way to reflect the idea that the innovator possesses superior information about demand. A more realistic assumption is that the innovator's information about demand is not perfect but still is better than the government's, and were this the assumption, it will be obvious that the qualitative nature of our results would not be altered.
} 
demand curve is $\mathrm{c}$, that is, $\mathrm{d}(\mathrm{q}(\mathrm{t}), \mathrm{t})=\mathrm{c}$. Thus social welfare exclusive of research investment is the social surplus,

$$
\mathrm{s}^{*}(\mathrm{t})=\int_{0}^{\mathrm{q}(\mathrm{t})}(\mathrm{d}(\mathrm{q} ; \mathrm{t})-\mathrm{c}) \mathrm{dq} .
$$

Consequently, the first-best research investment is that which maximizes

$$
\mathrm{p}(\mathrm{k}) \mathrm{s} *(\mathrm{t})-\mathrm{k}
$$

so that

$$
\mathrm{p}^{\prime}(\mathrm{k}) \mathrm{s}^{*}(\mathrm{t})=1
$$

identifies the first-best $\mathrm{k}$. If $\mathrm{k}(\mathrm{z})$ denotes the $\mathrm{k}$ that would be chosen if $\mathrm{z}$ is the payoff from an innovation, ${ }^{22}$ then the first-best $\mathrm{k}$ is written $\mathrm{k}(\mathrm{s} *(\mathrm{t}))$. First-best social welfare as a function of $\mathrm{t}$ is thus

$$
\mathrm{W}^{*}(\mathrm{t})=\mathrm{p}\left(\mathrm{k}(\mathrm{s} *(\mathrm{t})) \mathrm{s}^{*}(\mathrm{t})-\mathrm{k}(\mathrm{s} *(\mathrm{t}))\right.
$$

Figure 1 shows $\mathrm{s}^{*}(\mathrm{t})$ and $\mathrm{k}(\mathrm{s} *(\mathrm{t}))$.

\section{B. Patent Regime}

Under the patent regime (exemplifying intellectual property rights) the innovator has the exclusive right to sell the product resulting from an innovation. Hence, if he innovates, he will sell the monopoly quantity and earn monopoly profits. Specifically, let

$$
\begin{array}{ll}
\mathrm{q}_{\mathrm{m}}(\mathrm{t})=\text { monopoly quantity, and } \\
\pi(\mathrm{t})=\text { monopoly profits. }
\end{array}
$$

Knowing that an innovation would yield $\pi(\mathrm{t})$, the innovator will choose $\mathrm{k}$ to maximize

\footnotetext{
${ }^{22}$ That is, $\mathrm{k}(\mathrm{z})$ is determined by $\mathrm{p}^{\prime}(\mathrm{k}) \mathrm{z}=1$. Note that $\mathrm{k}(\mathrm{z})$ is increasing in $\mathrm{z}$ (implicitly differentiate $\mathrm{p}^{\prime}(\mathrm{k}) \mathrm{z}=1$ with respect to $\mathrm{z}$ to obtain $\left.\mathrm{k}^{\prime}(\mathrm{z})=-\mathrm{p}^{\prime}(\mathrm{k}) /\left(\mathrm{zp} \mathrm{p}^{\prime \prime}(\mathrm{k})\right)>0\right)$.
} 


$$
\mathrm{p}(\mathrm{k}) \pi(\mathrm{t})-\mathrm{k}
$$

so will choose $\mathrm{k}(\pi(\mathrm{t}))$.

Let us compare the outcome under patent to the first-best outcome. Now, as is familiar, $\mathrm{q}_{\mathrm{m}}(\mathrm{t})<\mathrm{q}(\mathrm{t})$, so that the social surplus under patent falls short of first-best social surplus $\mathrm{s}^{*}(\mathrm{t})$ by the deadweight loss

$$
l(\mathrm{t})=\int_{\mathrm{q}_{\mathrm{m}}(\mathrm{t})}^{\mathrm{q}(\mathrm{t})}(\mathrm{d}(\mathrm{q} ; \mathrm{t})-\mathrm{c}) \mathrm{dq} .
$$

Hence, social welfare under the patent regime given $t$ is

$$
\mathrm{W}_{\mathrm{P}}(\mathrm{t})=\mathrm{p}(\mathrm{k}(\pi(\mathrm{t})))[(\mathrm{s} *(\mathrm{t})-l(\mathrm{t})]-\mathrm{k}(\pi(\mathrm{t})) .
$$

This may be compared to first-best social welfare given t:

$$
\mathrm{W}^{*}(\mathrm{t})-\mathrm{W}_{\mathrm{P}}(\mathrm{t})=\left\{\left[\mathrm{p}\left(\mathrm{k}\left(\mathrm{s}^{*}(\mathrm{t})\right)\right) \mathrm{s}^{*}(\mathrm{t})-\mathrm{k}\left(\mathrm{s}^{*}(\mathrm{t})\right)\right]-\left[\mathrm{p}(\mathrm{k}(\pi(\mathrm{t}))) \mathrm{s}^{*}(\mathrm{t})-\mathrm{k}(\pi(\mathrm{t}))\right]\right\}+\mathrm{p}(\mathrm{k}(\pi(\mathrm{t}))) l(\mathrm{t}) .
$$

The first term, in braces, is clearly positive, and represents the welfare loss from inadequate investment in research under monopoly: because the monopolist's profit $\pi(t)$ is less than first-best social surplus $\mathrm{s}^{*}(\mathrm{t})$, he underinvests in research, $\mathrm{k}(\pi(\mathrm{t}))<\mathrm{k}(\mathrm{s} *(\mathrm{t}))$. The graph of $\mathrm{k}(\pi(\mathrm{t}))$ is shown in Figure 1. The second term is the expected deadweight loss due to monopoly pricing. In summary, we have

PROPOSITION 1: Under the patent system, there are two sources of welfare loss relative to first-best welfare: insufficient investment in research; and insufficient quantity of the innovation product sold, with accompanying deadweight loss, due to monopoly pricing.

These points are, of course, standard, ${ }^{23}$ they are set out so that we can contrast patent to reward.

\footnotetext{
${ }^{23}$ See, for example, Chapter 10 of Tirole (1988).
} 


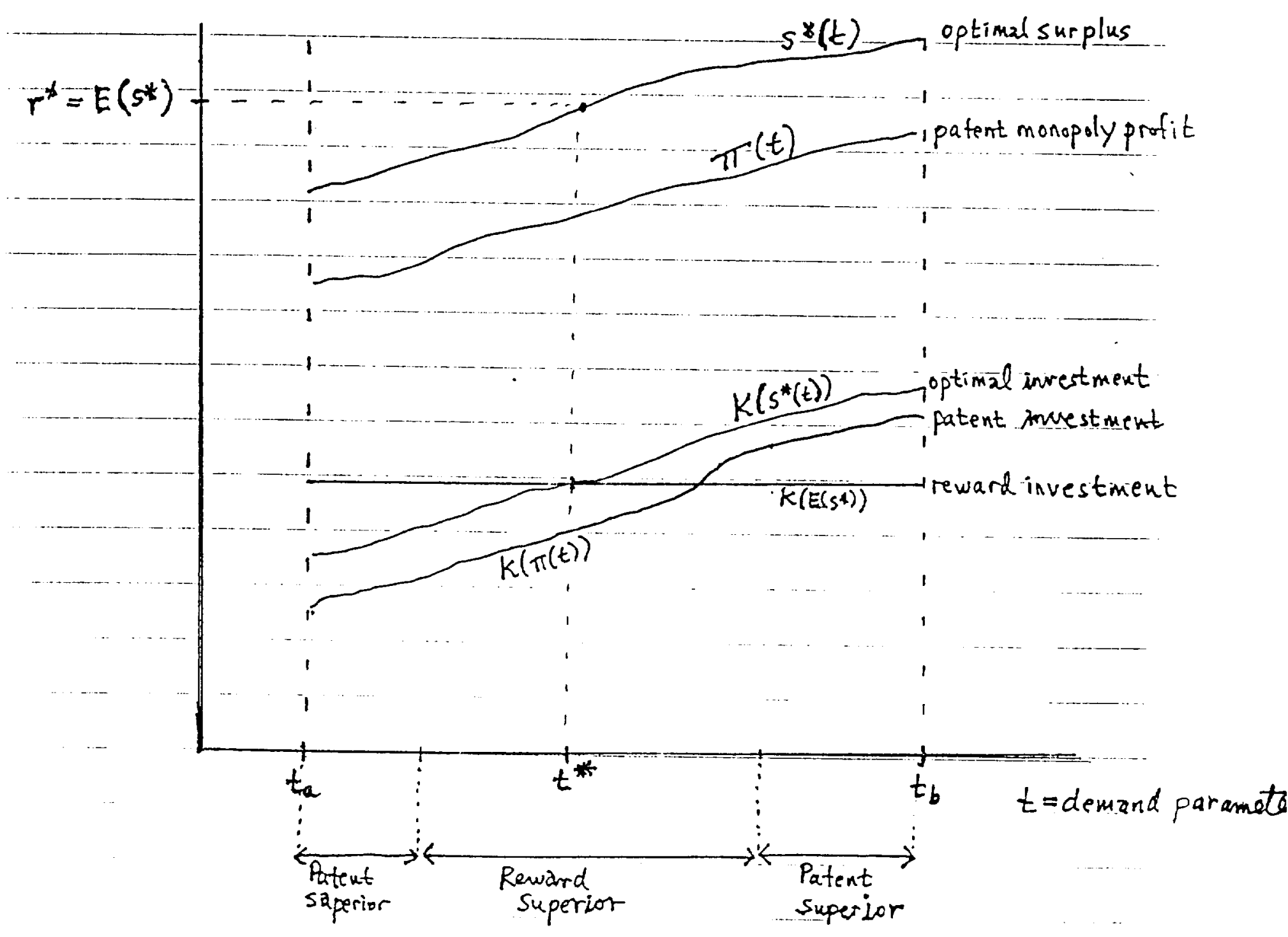

FIGURE 1 


\section{Reward Regime}

Under the reward regime, the government gives a reward to the innovator if he succeeds with an innovation, and it is assumed that the innovation information is placed in the public domain and made available to a competitive production industry. Hence, it is assumed that the product will be sold at a price of $\mathrm{c}$, so that zero profits will be made from production and total quantity produced will be $\mathrm{q}(\mathrm{t})$. Let

$\mathrm{r}=$ reward paid by government for an innovation.

The innovator's incentive to innovate is due entirely to the reward, since he makes no profits from sales. He will thus choose research investment to maximize

$$
\mathrm{p}(\mathrm{k}) \mathrm{r}-\mathrm{k} \text {, }
$$

so will choose $\mathrm{k}(\mathrm{r})$.

It follows that if - contrary to our assumption - the government were to possess perfect information about the demand curve $t$, the government could achieve a first-best outcome for each $t$ by setting the reward $r$ equal to $s^{*}(t)$ : the innovator would then choose $k\left(s^{*}(t)\right)$, the first-best investment in research; and the quantity produced is always optimal, $\mathrm{q}(\mathrm{t})$, under the reward system.

Because our assumption is that the government does not know t (and does not observe quantity sold), the reward $r$ must be fixed and independent of $t$. Social welfare as a function of the reward is

$$
\mathrm{W}_{\mathrm{R}}(\mathrm{r})=\int_{\mathrm{t}_{\mathrm{a}}}^{\mathrm{t}_{\mathrm{b}}} \mathrm{p}(\mathrm{k}(\mathrm{r})) \mathrm{s} *(\mathrm{t}) \mathrm{g}(\mathrm{t}) \mathrm{dt}-\mathrm{k}(\mathrm{r})=\mathrm{p}(\mathrm{k}(\mathrm{r})) \mathrm{E}\left(\mathrm{s}^{*}\right)-\mathrm{k}(\mathrm{r}),
$$

where $\mathrm{E}\left(\mathrm{s}^{*}\right)$ is the expected value of $\mathrm{s}^{*}(\mathrm{t})$; see Figure 1 . It follows that $(10)$ is maximized if $\mathrm{r}=$ 
$\mathrm{E}\left(\mathrm{s}^{*}\right) .^{24}$ That is, the optimal reward $\mathrm{r}^{*}$ is the expected social surplus from an innovation.

We can now compare social welfare under the reward system to first-best social welfare.

The difference beween the two is that research investment is the constant $\mathrm{k}\left(\mathrm{E}\left(\mathrm{s}^{*}\right)\right)$ under the reward system, whereas investment depends optimally on $\mathrm{t}$, equals $\mathrm{k}(\mathrm{s} *(\mathrm{t}))$, in the first-best situation. Under the reward system, research investment $\mathrm{k}\left(\mathrm{E}\left(\mathrm{s}^{*}\right)\right)$ is excessive relative to the firstbest when $\mathrm{s}^{*}(\mathrm{t})$ is below $\mathrm{E}\left(\mathrm{s}^{*}\right)$ and is inadequate when $\mathrm{s}^{*}(\mathrm{t})$ exceeds $\mathrm{E}\left(\mathrm{s}^{*}\right)$.

To summarize this section,

PROPOSITION 2: Under the reward system, the optimal reward $r^{*}$ equals the expected value of social surplus, $E\left(s^{*}\right)$, from an innovation. There is one source of welfare loss relative to first-best welfare: incorrect investment in research, which will be excessive or inadequate depending on whether actual surplus falls below or exceeds $E\left(s^{*}\right)$. There is no deadweight loss due to monopoly pricing if there is an innovation.

Note that the information the government requires to calculate the optimal reward is the density $\mathrm{g}(\mathrm{t})$ of the family of demand curves $\mathrm{d}(\mathrm{q} ; \mathrm{t})$ and the production cost $\mathrm{c}$ (in order to compute the surplus for each demand curve). The government does not need to know the probability function $\mathrm{p}(\mathrm{k})$.

\section{Patent versus Reward}

If we subtract social welfare under patent from that under reward, we obtain

$$
W_{R}(r)-W_{P}=W_{R}(r)-\int_{t_{a}}^{t_{b}} W_{P}(t) g(t) d t
$$

\footnotetext{
${ }^{24}$ Specifically, $\mathrm{p}(\mathrm{k}) \mathrm{E}\left(\mathrm{s}^{*}(\mathrm{t})\right)-\mathrm{k}$ is maximized over $\mathrm{k}$ if $\mathrm{k}=\mathrm{k}\left(\mathrm{E}\left(\mathrm{s}^{*}(\mathrm{t})\right)\right.$, so $\mathrm{r}$ must equal $\mathrm{E}\left(\mathrm{s}^{*}(\mathrm{t})\right)$.
} 


$$
=\int_{\mathrm{t}_{\mathrm{a}}}^{\mathrm{t}_{\mathrm{b}}}\left\{\left[\mathrm{p}(\mathrm{k}(\mathrm{E}(\mathrm{s} *))) \mathrm{s} *(\mathrm{t})-\mathrm{k}\left(\mathrm{E}\left(\mathrm{s}^{*}\right)\right)\right]-[\mathrm{p}(\mathrm{k}(\pi(\mathrm{t})))(\mathrm{s} *(\mathrm{t})-l(\mathrm{t}))-\mathrm{k}(\pi(\mathrm{t}))]\right\} \mathrm{g}(\mathrm{t}) \mathrm{dt} .
$$

The integrand in the second line reflects the two differences between reward and patent that we noted in the Introduction. First, under reward, there is no deadweight loss from insufficient production, whereas there is under patent. This constitutes an advantage of the reward system and tends to make the integrand positive (note that $l(\mathrm{t})$ is subtracted from $\mathrm{s}^{*}(\mathrm{t})$ in the second term). Second, under reward, the research investment is a constant $\mathrm{k}\left(\mathrm{E}\left(\mathrm{s}^{*}\right)\right)$, whereas under the patent, research investment depends on $t$, and equals $k(\pi(t))$. This difference may favor either patent or reward: when $\mathrm{s}^{*}(\mathrm{t})$ is sufficiently close to its mean, $\mathrm{E}\left(\mathrm{s}^{*}\right)$, investment will be closer to its first-best level under reward than under patent, where it is inadequate for all $t$; nevertheless, when $\mathrm{s}^{*}(\mathrm{t})$ is very different from $\mathrm{E}\left(\mathrm{s}^{*}\right)$, investment may be closer to first-best under patent than under reward.

Figure 1 helps to clarify the comparison. Let $t^{*}$ be the $t$ such that $\mathrm{s}^{*}(\mathrm{t})=\mathrm{E}\left(\mathrm{s}^{*}(\mathrm{t})\right)$. As shown in the Figure, reward is superior to patent for $t$ in a region around $t^{*}$. For $t$ sufficiently close to $t^{*}$ and within this region, reward is superior to patent for the double reason that investment is closer to first-best than under patent and deadweight monopoly pricing loss is eliminated; elsewhere in the region, reward is superior to patent even though investment is farther from first-best than under patent, because reward eliminates monopoly pricing deadweight loss. For t outside the region, patent is superior to reward because investment is sufficiently closer to first-best under patent than under reward as to overcome the deadweight loss due to monopoly pricing. This makes it clear that if enough probability mass is distributed close to $\mathrm{t}^{*}$, reward will be superior to patent, whereas if enough mass is not close to $t^{*}$, patent will be superior to 
reward. ${ }^{25}$ Hence, we have

PROPOSITION 3: Either the reward system or the patent system may be superior to the

other.

The foregoing discussion also leads to two observations about the comparison between reward and patent.

First, if the information that government has about demand is sufficiently good, then the reward system will dominate patent. Specifically, if the probability mass is sufficiently concentrated about $\mathrm{E}\left(\mathrm{s}^{*}\right)$, it follows from (11) that reward will dominate patent. ${ }^{26}$ This is because the research investment under reward will tend to be superior to (and higher than) that under patent and deadweight loss from monopoly pricing will be avoided.

Second, if the need for well-calibrated incentives to invest in research is sufficiently attenuated, then the reward system will dominate patent, because the factor of the elimination of deadweight loss from monopoly pricing will be of dominating importance. One way to make this notion precise is to consider the family of research investment functions $\mathrm{p}(\mathrm{k} \lambda)$, where $\lambda$ is a positive parameter. Note that the need for incentives to invest in research becomes small as $\lambda$ grows large because the probability of innovation can be made high at low cost as $\lambda$ grows large: for any $\mathrm{k}>0, \mathrm{p}(\mathrm{k} \lambda) \rightarrow \overline{\mathrm{p}}$ as $\lambda \rightarrow \infty$, where $\overline{\mathrm{p}}=\lim \mathrm{p}(\mathrm{k})$ as $\mathrm{k} \rightarrow \infty$. And indeed, inspection of (11)

\footnotetext{
${ }^{25}$ We have also constructed numerical examples (see the Appendix) in which patent is superior to reward and in which reward is superior to patent.

${ }^{26}$ This follows from continuity considerations and the fact that at $t^{*}$, the integrand is positive, for at $\mathrm{t}^{*}$, $\left.\left[\mathrm{p}\left(\mathrm{k}\left(\mathrm{E}\left(\mathrm{s}^{*}\right)\right)\right) \mathrm{s}^{*}(\mathrm{t})-\mathrm{k}\left(\mathrm{E}\left(\mathrm{s}^{*}\right)\right)\right]=\left[\mathrm{p}\left(\mathrm{k}\left(\mathrm{E}\left(\mathrm{s}^{*}\right)\right)\right) \mathrm{E}\left(\mathrm{s}^{*}\right)-\mathrm{k}\left(\mathrm{E}\left(\mathrm{s}^{*}\right)\right)\right]>\mathrm{p}\left(\mathrm{k}\left(\pi\left(\mathrm{t}^{*}\right)\right)\right) \mathrm{E}\left(\mathrm{s}^{*}\right)-\mathrm{k}\left(\pi\left(\mathrm{t}^{*}\right)\right)\right]>\mathrm{p}\left(\mathrm{k}\left(\pi\left(\mathrm{t}^{*}\right)\right)\right)\left(\mathrm{E}\left(\mathrm{s}^{*}\right)-l\left(\mathrm{t}^{*}\right)\right)-$ $\left.\mathrm{k}\left(\pi\left(\mathrm{t}^{*}\right)\right)\right]$.
} 
shows that reward will be superior to patent if $\lambda$ is sufficiently high. ${ }^{27}$

Additionally, we observe that the information the government needs to make the comparison between patent and reward is not only the density $\mathrm{g}(\mathrm{t})$, the demand curves $\mathrm{d}(\mathrm{q} ; \mathrm{t})$, and the production cost $\mathrm{c}$, but also the probability function $\mathrm{p}(\mathrm{k}){ }^{28}$

\section{E. Optional Reward Regime}

Under the optional reward regime, the innovator can choose whether to take the government reward $\mathrm{r}$ (in which case the innovation information is placed in the public domain) or instead to obtain a patent. Hence, the innovator will choose the reward if and only if $r \geq \pi(t)$; he will choose patent when the demand curve is such that monopoly profits would be high, as is illustrated in Figure 2. Note that if $r<\pi\left(t_{a}\right)$, then the innovator will always behave the same way — choose patent and obtain $\pi(\mathrm{t})$ - so that in determining the optimal reward, we can restrict attention to $r \geq \pi\left(t_{a}\right)$. Now let $t(r)$ denote $\pi^{-1}(r)$ for $r$ in $\left[\pi\left(t_{a}\right), \pi\left(t_{b}\right)\right]$ and let $t(r)=t_{b}$ for $r>\pi\left(t_{b}\right)$. Then social welfare under the optional reward system is

$$
\mathrm{W}_{\mathrm{O}}(\mathrm{r})=\int_{\mathrm{t}_{\mathrm{a}}}^{\mathrm{t}(\mathrm{r})}\left[\mathrm{p}(\mathrm{k}(\mathrm{r})) \mathrm{s}^{*}(\mathrm{t})-\mathrm{k}(\mathrm{r})\right] \mathrm{g}(\mathrm{t}) \mathrm{dt}+\int_{\mathrm{t}(\mathrm{r})}^{\mathrm{t}_{\mathrm{b}}}[\mathrm{p}(\mathrm{k}(\pi(\mathrm{t})))(\mathrm{s} *(\mathrm{t})-l(\mathrm{t}))-\mathrm{k}(\pi(\mathrm{t}))] \mathrm{g}(\mathrm{t}) \mathrm{dt} .
$$

The derivative of (12) is

$\mathrm{W}_{\mathrm{O}}{ }^{\prime}(\mathrm{r})=\mathrm{k}^{\prime}(\mathrm{r})\left[\mathrm{p}^{\prime}(\mathrm{k}(\mathrm{r})) \mathrm{E}\left(\mathrm{s}^{*} \mid \mathrm{t} \leq \mathrm{t}(\mathrm{r})\right)-1\right] \mathrm{G}(\mathrm{t}(\mathrm{r}))+\mathrm{t}^{\prime}(\mathrm{r}) \mathrm{p}(\mathrm{k}(\mathrm{r})) l(\mathrm{t}(\mathrm{r})) \mathrm{g}(\mathrm{t}(\mathrm{r}))$,

where $\mathrm{G}$ is the cumulative distribution function of $\mathrm{g}$ and $\mathrm{E}\left(\mathrm{s}^{*} \mid \mathrm{t} \leq \mathrm{t}(\mathrm{r})\right)$ is the expected value of $\mathrm{s}^{*}(\mathrm{t})$ conditional on $\mathrm{t} \leq \mathrm{t}(\mathrm{r})$. The first term in (13) reflects the inframarginal effect of raising the

\footnotetext{
${ }^{27} \mathrm{It}$ is clear that as $\lambda \rightarrow \infty, \mathrm{k}\left(\mathrm{E}\left(\mathrm{s}^{*}\right)\right)$ and $\mathrm{k}(\pi(\mathrm{t}))$ both approach 0 , and $\mathrm{p}\left(\mathrm{k}\left(\mathrm{E}\left(\mathrm{s}^{*}\right)\right)\right)$ and $\mathrm{p}(\mathrm{k}(\pi(\mathrm{t}))$ both approach $\overline{\mathrm{p}}$. Hence, the integrand in (11) approaches $\overline{\mathrm{p}} l(\mathrm{t})>0$.

${ }^{28}$ The government will need the same information to compute the optimal reward under the optional reward system, and to make comparisons between that system and the other systems.
} 


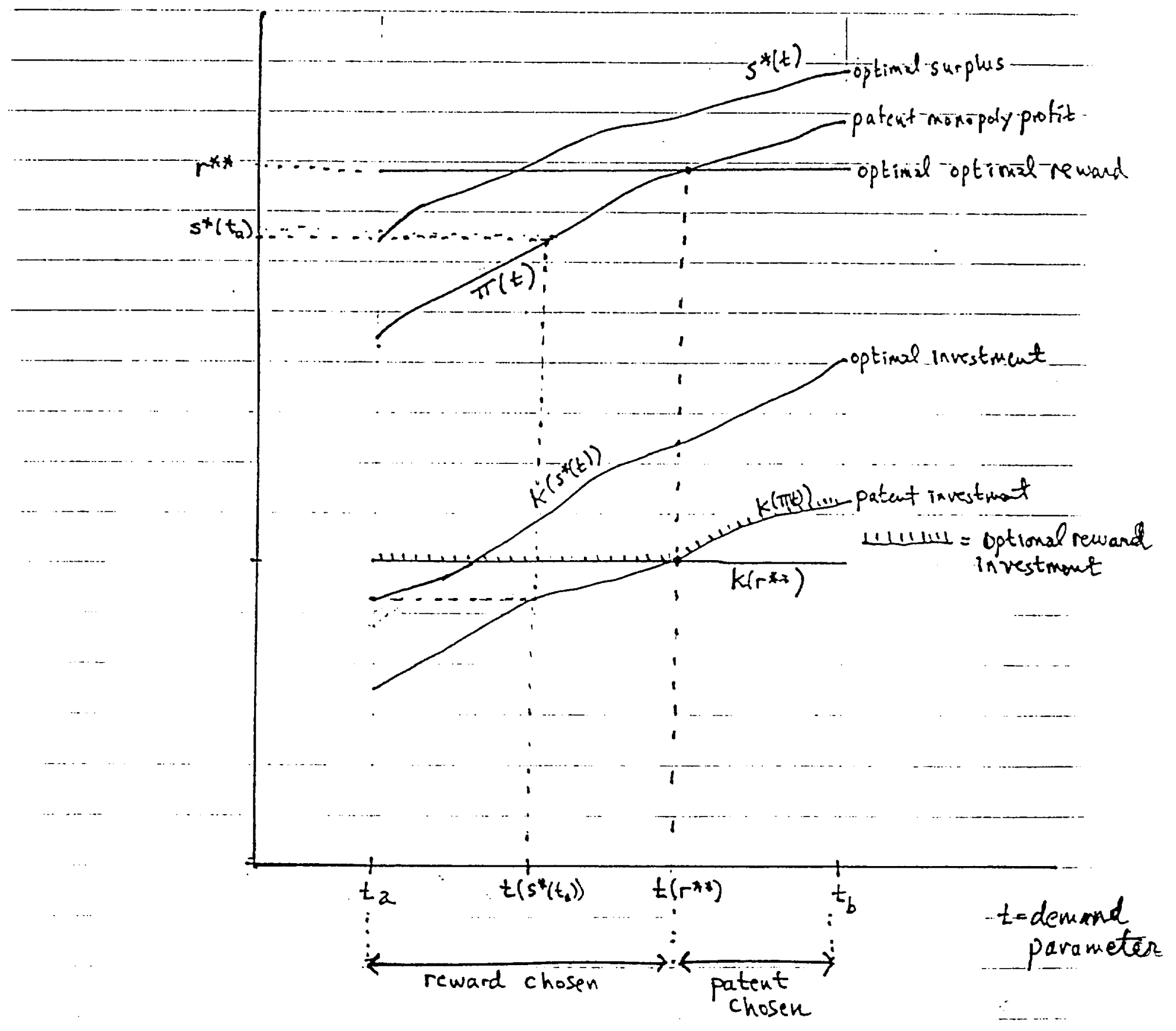

FIGURE 2 
reward: the influence of the increase in research investment in cases where the innovator chooses the reward. Note that the term in brackets, $\left[\mathrm{p}^{\prime}(\mathrm{k}(\mathrm{r})) \mathrm{E}\left(\mathrm{s}^{*} \mid \mathrm{t} \leq \mathrm{t}(\mathrm{r})\right)-1\right]$, is the expected net return from more investment in such cases. The second term in (13) is the marginal effect of raising the reward: just inducing the innovator to accept the reward rather than to obtain a patent. In this circumstance, the innovator, by accepting the reward, does not alter his research investment (since the reward just equals his monopoly profits); the only change is that the monopoly pricing deadweight loss $l(\mathrm{t}(\mathrm{r}))$ is eliminated, explaining that factor in the second term.

Now the second term in (13) is non-negative (it is clear that $\mathrm{t}^{\prime}(\mathrm{r})$ is non-negative). Hence, if the first term in (13) is positive, (13) will be positive. The first term will be positive if $\left[\mathrm{p}^{\prime}(\mathrm{k}(\mathrm{r})) \mathrm{E}\left(\mathrm{s}^{*} \mid \mathrm{t} \leq \mathrm{t}(\mathrm{r})\right)-1\right]$ is positive, and that will be so if and only if $\mathrm{r}<\mathrm{E}\left(\mathrm{s}^{*} \mid \mathrm{t} \leq \mathrm{t}(\mathrm{r})\right)$. This in turn certainly will be true for $\mathrm{r} \leq \mathrm{s} *\left(\mathrm{t}_{\mathrm{a}}\right)$, because $\mathrm{s}^{*}\left(\mathrm{t}_{\mathrm{a}}\right)<\mathrm{E}\left(\mathrm{s}^{*} \mid \mathrm{t} \leq \mathrm{t}(\mathrm{r})\right)$ for any $\mathrm{r}$. Thus (13) must be positive for $r \leq \mathrm{s}^{*}\left(\mathrm{t}_{\mathrm{a}}\right)$, which implies that the optimal $\mathrm{r}$, denoted $\mathrm{r}^{* *}$, must exceed $\mathrm{s}^{*}\left(\mathrm{t}_{\mathrm{a}}\right)$. We therefore have

PROPOSITION 4: Under the optional reward system, the innovator chooses the reward when monopoly profit would be lower; otherwise he chooses patent. The optimal optional reward, $r^{* *}$, exceeds the minimum social surplus, $s^{*}\left(t_{a}\right)$.

We observe that if $r^{* *} \geq \pi\left(t_{b}\right)$, then the optional reward will always be chosen, so the outcome is equivalent to that if $\mathrm{r}^{* *}$ were a mandatory reward.

\section{F. Optional Reward versus Patent}

We can immediately show the following.

PROPOSITION 5: The optional reward system is superior to the patent system.

This result is really a corollary of Proposition 4. In particular, as we observed, the patent 
system is equivalent to an optional reward system with $r=\pi\left(t_{\mathrm{a}}\right)$, because then the patent would always be chosen. But since $\mathrm{r}^{* *}>\mathrm{s}^{*}\left(\mathrm{t}_{\mathrm{a}}\right)$, we know that $\mathrm{r}^{* *}$ exceeds $\pi\left(\mathrm{t}_{\mathrm{a}}\right)$; hence, the optimal optional reward system must be superior to the patent system.

Although the above paragraph demonstrates the result, it is perhaps best understood by considering why the optional reward system with a reward of $\mathrm{s}^{*}\left(\mathrm{t}_{\mathrm{a}}\right)$ is superior to patent (and $a$ fortiori why the optional reward system with the optimal reward must be superior to patent). If the reward is $\mathrm{s}^{*}\left(\mathrm{t}_{\mathrm{a}}\right)$, the reward will be chosen by the innovator whenever monopoly profits are less than this amount, that is, the reward will be chosen when $t$ is in the interval $\left[\mathrm{t}_{\mathrm{a}}, \mathrm{t}\left(\mathrm{s}^{*}\left(\mathrm{t}_{\mathrm{a}}\right)\right)\right)$; see Figure 2. For any $\mathrm{t}$ in this interval, it is apparent that the choice of reward over patent must increase social welfare: the deadweight loss due to monopoly is eliminated; and since the innovator chooses research investment of $\mathrm{k}\left(\mathrm{s}^{*}\left(\mathrm{t}_{\mathrm{a}}\right)\right)$ instead of $\mathrm{k}(\pi(\mathrm{t}))$, and $\mathrm{k}(\pi(\mathrm{t}))<\mathrm{k}\left(\mathrm{s}^{*}\left(\mathrm{t}_{\mathrm{a}}\right)\right)$ $<\mathrm{k}\left(\mathrm{s}^{*}(\mathrm{t})\right)$, the increase in research investment also raises social welfare. Because, then, social welfare is higher under optional reward whenever the reward is chosen and is the same as under patent when the reward is not chosen, social welfare must have risen.

\section{G. Optional Reward versus Reward}

We have yet to compare the optional reward system to the reward system, which is of a mandatory nature. We have

PROPOSITION 6: Either the optional reward system or the reward system may be superior to the other.

That the optional reward system may be superior to reward is clear: the patent system may be superior to reward, according to Proposition 3; and whenever the patent system is superior to reward, the optional reward system must be superior to reward, for optional reward is superior to 
patent, according to Proposition 5. ${ }^{29}$ The explanation is essentially that under optional reward, when the demand curve is high, patent will be chosen and incentives to invest will thus not be dulled by a too-low-under-the-circumstances reward. This investment-incentive advantage of optional reward may be more important than the disadvantage of deadweight loss from patent monopoly-pricing.

That the reward system may be superior to optional reward is possible for related reasons. When the demand curve is high and patent is chosen under optional reward, the investmentincentive advantage of optional reward may be less important than the disadvantage of deadweight loss from patent monopoly-pricing. Reward, being mandatory, prevents the potential problem that patent would be chosen when the demand curve is high. ${ }^{30}$

\section{H. Rewards Conditional on Quantity Sold}

Suppose now that government can observe quantity q sold and base rewards on this. Our analysis would then be modified in straightforward ways. In Section IIC, the reward would not be a constant but a function $r(q)$. The innovator would then choose $k(r(q(t)))$ : the innovator knows $t$, so can calculate what the equilibrium quantity sold $q(t)$ would be, and thus the reward $\mathrm{r}(\mathrm{q}(\mathrm{t}))$ he would receive. (Note that the innovator does not influence $\mathrm{q}(\mathrm{t})$, as he is one seller in a competitive market. ${ }^{31}$ ) Hence, social welfare (10) given the function $\mathrm{r}(\mathrm{q})$ would become

\footnotetext{
${ }^{29}$ It is also possible for optional reward to be superior to reward when reward is superior to patent.

${ }^{30} \mathrm{We}$ have constructed a numerical example in which reward may be superior to optimal reward; see the Appendix.

${ }^{31} \mathrm{~A}$ factor from which we abstract is that an innovator might have an incentive to make substantial purchases, because the optimal reward per unit might exceed marginal production cost. For example, the reward for each pill sold of a new drug might exceed its production cost, in which case the innovating company would have an incentive to make large purchases of its pill. Such manipulation of quantity sold would have to be policed by government in a quantity-based reward regime.
} 


$$
\begin{aligned}
\mathrm{W}_{\mathrm{R}}(\mathrm{r}(\mathrm{q}))=\int_{\mathrm{t}_{\mathrm{a}}}^{\mathrm{t}_{\mathrm{b}}}\left[\mathrm{p}\left(\mathrm{k}(\mathrm{r}(\mathrm{q}(\mathrm{t}))) \mathrm{s}^{*}(\mathrm{t})-\mathrm{k}(\mathrm{r}(\mathrm{q}(\mathrm{t})))\right] \mathrm{g}(\mathrm{t}) \mathrm{dt}\right. \\
=\int_{\mathrm{q}_{\mathrm{a}}}^{\mathrm{q}_{\mathrm{b}}}[\mathrm{p}(\mathrm{k}(\mathrm{r}(\mathrm{q}))) \mathrm{E}(\mathrm{s} * \mid \mathrm{q})-\mathrm{k}(\mathrm{r}(\mathrm{q}))] \mathrm{f}(\mathrm{q}) \mathrm{dq},
\end{aligned}
$$

where $\mathrm{E}\left(\mathrm{s}^{*} \mid \mathrm{q}\right)$ is the mean of $\mathrm{s}^{*}(\mathrm{t})$ given that $\mathrm{q}(\mathrm{t})=\mathrm{q}, \mathrm{f}(\mathrm{q})$ is the density of $\mathrm{q}$ derived from $\mathrm{g}(\mathrm{t})$

(that is, $\mathrm{f}(\mathrm{q})$ is the density of the set of $\mathrm{t}$ such that $\mathrm{q}(\mathrm{t})=\mathrm{q})$, and $\mathrm{q}_{\mathrm{i}}=\mathrm{q}\left(\mathrm{t}_{\mathrm{i}}\right)$. It is evident from $\left(10^{\prime}\right)$ that, for any $\mathrm{q}$, the socially optimal $\mathrm{r}(\mathrm{q})$ is $\mathrm{E}\left(\mathrm{s}^{*} \mid \mathrm{q}\right)$; the optimal reward function is the mean social surplus conditional on the demand curve being such that the quantity sold at price c was the observed quantity.

Clearly, the comparison between reward schemes and the patent system would be qualitatively unchanged from that discussed above. However, because the quantity-based optimal reward is generally different from the unconditional optimal reward (because $\mathrm{E}(\mathrm{s} * \mid \mathrm{q})$ is generally different from $\mathrm{E}\left(\mathrm{s}^{*}\right)$ ) and thus is superior to it, the quantity-based reward would more often be superior to patent than the unconditional reward is superior to patent. Likewise, the quantitybased optional reward would be superior to the unconditional optional reward, and would thus be more advantageous relative to the patent system than would the unconditional optional reward.

\section{Discussion}

We comment here on a number of issues that were omitted from the model and on its interpretation.

An alternative system: patent and reward. A policy that we did not consider is one in which an innovator always obtains a patent and is also given a reward. This system is superior to patent, since the problem of underinvestment is alleviated by payment of a reward. (The optimal 
reward would equal the expected value of the difference between social surplus and monopoly profits at the monopoly quantity — the social surplus not captured by the patent holder.) The system might or might not be superior to reward or optional reward, for reasons analogous to those relating to the comparison between patent and reward.

Government's ability to obtain information about the value of innovations. As we stressed in the analysis, government's knowledge about the social value of innovations, embodied in its probability distribution over demand curves, is important to the performance of the reward system and to that of the optional reward system (even though the latter dominates patent no matter how poor government's knowledge). In fact, one supposes that the government could obtain significant information about demand. Most obviously, the government can base its rewards on sales data, which should be relatively easy to obtain; thus, the version of rewards discussed in Section IIH is the most relevant one to consider. (Note that if rewards are based on sales, the government should not fear that it would be flooded by claimants for rewards with inferior or meaningless innovations - they would not generate products that would pass the market test.) The government could also attempt to measure more about the demand curve than sales at the market price; it could estimate demand elasticities, undertake surveys to determine the character and frequency of use of, for example, computer software, musical recordings, cinematic and television productions. As events unfold and information flows to the government, it could appropriately supplement rewards, perhaps on an annual basis. In past proposals for reward systems, payments based on sales and other information that government receives have sometimes been discussed (see especially Polanvyi (1943 pp. 67-69)). It would be a gross mistake to envision the reward as having to be premised on the government's estimate of valuation at the 
time an innovation is registered.

Government's information versus innovators'. We have just mentioned the ability of government to obtain information about demand, but we have not considered how good innovators' information is and its relation to government's. In this regard, two comments should be made, which together suggest that the factor of innovators' superiority of information may be less important than it initially appears to be. First, innovators' information will often be substantially imperfect ex ante, at the time when they are deciding on research investment — the crucial period for assessment of innovators' information. Second, government's information will often be reasonably good ex post, which is the pertinent period for assessment of government information when rewards are based on sales-related evaluations of worth. Thus, when rewards are based on ex post data, the informational comparison that bears on the choice between rewards and intellectual property rights is that between innovators' ex ante information and government's ex post information (that innovators' ex ante information may be superior to government's ex ante information would be irrelevant to the choice between rewards and property rights). This point can be put more sharply. Suppose, as is not implausible, that government's ex post, sales-related information about demand is as good as innovators' ex ante information, when they are deciding on research investment. Then innovators enjoy no informational advantage that favors intellectual property rights, and mandatory rewards (not just optional rewards) are unambiguously superior to intellectual property rights. ${ }^{32}$

\footnotetext{
${ }^{32}$ To amplify, let the innovator's ex ante information be $\mathrm{z}$, which can be written $\mathrm{z}(\mathrm{q})$, because the assumption is that $\mathrm{q}$ is at least as informative as $\mathrm{z}$. Then it is clear that a social optimum given the constraint that the innovator knows only $\mathrm{z}$ when he chooses $\mathrm{k}$ can be achieved under the reward system if the reward equals $\mathrm{E}\left(\mathrm{s}^{*} \mid \mathrm{q}\right)$, whereas under the patent system, $\mathrm{k}$ will be suboptimal and the amount sold will be too low.
} 
Race to be first. The optimal magnitude of the reward would be affected in practice by a consideration that we did not study in our model: the race among potential innovators to be the first to innovate. As is emphasized in the literature on patent, this race leads to the possibility of overinvestment in research because the private return to being first may exceed its social value. ${ }^{33}$ Likewise, under a reward system, there would be a race to be first, and it might lead to excessive investment in research, lowering the optimal reward. Because the race to be first is a factor that afflicts both systems, and because the information needed to address it under either seems to be of the same character, consideration of the race to be first does not seem to bear on the comparison between reward and patent.

Subsequent innovations. We did not discuss the issue of subsequent innovations, that is, improvements to innovations or new innovations depending on past ones. In this regard, two points are of interest. First, under the intellectual property rights system, subsequent innovations may be stymied by refusal of holders of property rights to allow improvements; there may be breakdowns in bargaining between the holders and innovators. ${ }^{34} \mathrm{~A}$ famous example of this occurred when James Watt, holder of an early steam engine patent, denied licenses to improve it to Jonathan Hornblower and Richard Trevithick, who had to wait for Watt's patent to expire in 1800 before they could develop their high-pressure engine. ${ }^{35}$ Under a reward system, this would not have been the case, for Watt's steam engine would have been in the public domain, and Hornblower and Trevithick would have been free to improve it immediately. (Indeed, as noted in

\footnotetext{
${ }^{33}$ See Chapter 10 of Tirole (1988).

${ }^{34}$ To some degree, this problem can be addressed by legal rules that force the right holder to allow an innovator to make and sell an improved product; this is what compulsory licensing rules of patent law do.

${ }^{35}$ See Scherer (1980 p. 452).
} 
the Introduction, this was one of the arguments in favor of the reward system emphasized in the $19^{\text {th }}$ century debates. ${ }^{36}$ ) The second point of note is that government's problem of determining rewards is made more difficult when the value of an innovation is in part that it leads to subsequent innovations. However, government's problem in administering the patent system is also made more difficult by the possibility of subsequent innovations (notably, in determining issues of patent scope — which subsequent innovations will be considered infringing), and for closely-related informational reasons. Hence, it is not clear the extent to which, or whether, the added informational difficulty presented by subsequent innovations favors patent over reward.

Administrative costs. Under a reward system, administrative costs would be incurred by the government in deciding upon rewards, and there would be litigation about rewards between innovators and government, as well as between innovators who contest each other's rewards. However, there would also be a savings in administrative costs relative to the patent or copyright systems: under these systems, intellectual property rights have to be protected by the state, parties often make efforts to determine if their rights have been violated and also to ascertain if they are violating someone's else's rights, and litigation costs are incurred in disputes over rights; but under the reward system, there are no intellectual property rights to generate such costs. On a priori grounds, one cannot say whether the administrative cost savings of the reward system would outweigh the administrative costs that the reward system would entail. ${ }^{37}$

\footnotetext{
${ }^{36}$ See, for example, Macfie (1875 p. 5) who states, "when an invention is patented, the reward being monopoly, a stop is put to improvement....If we substituted for monopoly a sensible system of grants in money, thus preserving a pecuniary stimulus to publish inventions, I predict that almost every new machine or process would be studied, scrutinized, and subjected to such an amount of diversified and intelligent thought that...it would be greatly perfectionated."

${ }^{37}$ In considering this paragraph, the complicating factor that administrative costs are really endogenous should be borne in mind. We can imagine an intellectual property rights system that is less expensive than the one we have, and we can imagine a reward system that involves low administrative costs because it bases rewards on a simple formula, such as
} 
Tax-financing cost of a reward system. Reward systems have to be financed, and we presume through income taxation, but that involves a labor-supply-related distortionary cost, something that was not considered in our model. Hence, the potential case for reward is less strong than is suggested by our analysis. However, there are reasons to believe that financing innovation through income taxation involves lower distortionary cost than financing innovation through the grant of intellectual property rights. In particular, we know from the tax literature that raising funds through income taxation is superior to doing so through commodity taxation (which is essentially equivalent to granting intellectual property rights); this conclusion presumes that the income tax can be adjusted in an optimal way to raise funds. ${ }^{38}$ If one takes the view that the income tax cannot be optimally adjusted, then there is still some basis for believing that the income tax involves less distortion than intellectual property rights: income taxation is equivalent to a uniform tax on all goods, whereas intellectual property rights involves concentrated taxes in the form of monopoly prices on just a subset of goods; and raising a given amount through a uniform tax on all goods generally involves less deadweight loss than through a tax on a subset of goods.

Further merits of the optional reward system. The optional reward system not only has the theoretical advantage that it is superior to intellectual property rights, it has the practical, political advantage that industry should not object to it, as it can only raise firms' profits. Moreover, the fear that government would act suboptimally, and give unduly conservative

a percentage of sales revenues.

${ }^{38}$ The point that income taxes are superior to commodity taxes is presented, for example, in Stiglitz (1987). See also Kaplow (1996), who emphasizes that there need not be any distortionary cost associated with raising greater income tax revenues to finance a government program if the income tax is optimally adjusted rather than mechanically increased. 
rewards, would be less an issue under an optional reward scheme because innovators can always obtain intellectual property rights. Indeed, just because of innovators' option, the government's temptation to pay too little might be checked under an optional reward system. Thus, were there an interest in actual adoption of a reward scheme, an optional version might be the best type to propose initially. (As noted earlier, the plan set out by Polanvyi (1943) was mainly optional in nature, as are schemes for the government to offer to purchase patents.)

Importance of the advantages of reward systems. To appreciate the possible advantages of reward systems, it is helpful to consider areas of innovation where the social losses due to intellectual property rights are likely to be high, namely, where the difference between price and production cost (after innovation) is large. Such areas of innovation may be exemplified by development of pharmaceuticals, computer software, and recorded music and visual products. Here, prices are often substantial in relation to production cost; drugs may sell for many times their marginal production cost, the price of computer software is generally nontrivial even though its marginal production cost is essentially zero (it can be downloaded from the Internet), and similar statements can be made about CD recordings, cable TV broadcasts, and first-run movies. In a regime with rewards, drugs would be far cheaper and more widely used, all computer software would be free, and electronically recorded materials would be inexpensive, arguably engendering significant increases in consumer welfare. Moreover, there would also be potential gains from enhanced incentives to innovate, as profits from patent and copyright may fall far short of consumer surplus. For example, Kremer (1997) suggests that studies of the social versus the private returns from research indicate that private profits from research might well be less than one third of the social returns. Because optimal rewards would reflect the social returns, rewards 
would increase overall incentives to invest.

\section{Conclusion}

Reward systems, or optional reward systems, and especially those based on sales-related information, appear on reflection to hold great promise as alternatives to our system of intellectual property rights, because there is no necessity to marry the incentive to innovate to conferral of monopoly power in innovations. As such, serious study of the possibility of reward systems, with a view towards their implementation at least on an experimental, partial basis, is worth contemplating. 


\section{References}

Arrow, Kenneth J. "Economic Welfare and the Allocation of Resources to Invention," in Essays in the Theory of Risk-Bearing. Chicago: Markham, 1971, pp. 144 - 163.

Dutton, H.I. The patent system and inventive activity during the industrial revolution 1750-1852. Manchester: Manchester University Press, 1984.

Goldstein, Paul. Copyright, patent, trademark and related state doctrines, Revised third ed. Westbury, N.Y.: Foundation Press, 1993.

Kaplow, Louis. "The Optimal Supply of Public Goods and the Distortionary Cost of Taxation." National Tax Journal, December 1996, 49 (4), pp. 513- 33.

Kremer, Michael, "Patent Buyouts: A Mechanism for Encouraging Innovation.” Mimeo, MIT, 1997.

Lord Hailsham of St. Marylebone. Halsbury's laws of england, Fourth edition reissue, Vol. 35. London: Butterworths, 1994.

Macfie, R.A. Recent discussions on the abolition of patents for inventions. London: Longmans, Green, Reader, and Dyer, 1869.

Macfie, R.A. The patent question in 1875. London: Longmans, Green, 1875.

Macfie, R.A. Copyright and patents for inventions, vol II., patents. Edinburgh: T. \& T. Clark, 1883.

Machlup, Fritz. An economic review of the patent system. Washington: United States Government Printing Office, 1958.

Machlup, Fritz and Edith Penrose. "The Patent Controversy in the Nineteenth Century." Journal of Economic History, May 1950, 10 (1), pp. 1-29.

MacLeod, Christine. Inventing the industrial revolution. Cambridge: Cambridge University Press, 1988.

Mill, John Stuart. Principles of political economy. Boston: Lee and Shephard, 1872 (1848).

Polanvyi, Michael. "Patent Reform.” Review of Economic Studies, Winter 1943, 11 (1), pp. 6176. 
Prager, Frank D. "A History of Intellectual Property from 1545 to 1787 ." Journal of the Patent Office Society, November 1944, 26 (11), pp. 711- 60.

Scherer, F. M. Industrial market structure and economic performance, Second ed. Boston: Houghton Mifflin, 1980.

Scherer, F. M., and David Ross. Industrial market structure and economic performance, Third ed. Boston: Houghton Mifflin, 1990.

Scotchmer, Suzanne, "On the Optimality of the Patent System.” Mimeo, University of California, Berkeley, 1997.

Scotchmer, Suzanne, "On the Optimality of the Patent Renewal System." Mimeo, University of California, Berkeley, 1998.

Sinnot, John P. World patent law and practice, Vol. 2M. New York: Matthew Bender, 1988.

Stiglitz, Joseph E. "Pareto Efficient and Optimal Taxation and the New New Welfare Economics," in A.J. Auerbach and M. Feldstein, eds., Handbook of public economics, Vol. II. Amsterdam: North-Holland, 1987, pp. 991-1042.

Tirole, Jean. The theory of industrial organization. Cambridge: MIT Press, 1988.

Wright, Brian D., "The Economics of Invention Incentives: Patents, Prizes, and Research Contracts." American Economic Review, September 1983, 73 (4), pp. 691-707. 


\section{Appendix: Numerical Example}

We describe here a numerical example that illustrates the model analyzed. Let $\mathrm{p}(\mathrm{k})=$ $(\exp [.1 \mathrm{k}]-1) / \exp [.1 \mathrm{k}]$ and $\mathrm{c}=5$. Suppose that demand curves are kinked (for computational convenience) and given by $\mathrm{d}(\mathrm{q} ; \mathrm{t})=\min (.5 \mathrm{t}-.05 \mathrm{q}+5,200 \mathrm{t}-20 \mathrm{q}-1800)$, so that the kink occurs at $\mathrm{q}=10 \mathrm{t}-90.476$. The parameter $\mathrm{t}$ is in $\left[\mathrm{t}_{\mathrm{a}}, \mathrm{t}_{\mathrm{b}}\right]=[10,20]$ and is distributed according to the truncated normal distribution with mean 15 and variance 4 . That is $g(t)=\left(1 /(8 \pi)^{1 / 2}\right) \exp [-(\mathrm{t}-$ $\left.15)^{2} / 8\right]+.0012419$. The following can be verified:

(i) First-best surplus $\mathrm{s} *(\mathrm{t})=2.5 \mathrm{t}^{2}-204.139, \mathrm{k}(\mathrm{s} *(\mathrm{t}))=10 \ln [.1 \mathrm{~s} *(\mathrm{t})], \pi(\mathrm{t})=45.238 \mathrm{t}-$ $409.3, l(\mathrm{t})=.51076$, and $\mathrm{k}(\pi(\mathrm{t}))=10 \ln [.1 \pi(\mathrm{t})]$.

(ii) The optimal reward $\mathrm{r}^{*}=\mathrm{E}\left(\mathrm{s}^{*}\right)=367.62$, and $\mathrm{k}\left(\mathrm{E}\left(\mathrm{s}^{*}\right)\right)=10 \ln [36.762]$.

(iii) Reward is superior to patent: social welfare under reward is 321.57 and under patent it is 321.51. However, if the distribution of $\mathrm{t}$ is modified from the truncated normal to the uniform distribution in $[10,20]$, then patent is superior to reward: social welfare under reward is 332.84 and under patent it is 334.04 .

(iv) The optimal optional reward $\mathrm{r}^{* *}=327.2$, and this exceeds $\mathrm{s} *\left(\mathrm{t}_{\mathrm{a}}\right)=45.35$. The optional reward is superior to patent: social welfare under the optimal optional reward is 321.62 , whereas social welfare under the patent system is 321.51 .

(v) The optional reward is superior to reward: social welfare under the optional reward is 321.62, whereas social welfare under the reward system is 321.57 . However, we can modify the distribution of $\mathrm{t}$ to illustrate that reward may be superior to optimal reward. Let $\mathrm{t}$ be uniformly distributed at height 9 over the subinterval $[14.95,15.05]$ and uniformly distributed at height 1 
over the subinterval $[17.9,18]$. Then reward is superior to optional reward: under reward, social welfare is 336.218 , and under optimal optional reward, social welfare is 336.214. (The reason that reward is superior may be explained roughly by two observations: reward functions well because $90 \%$ of the probability mass is in a concentrated region, about 15; reward is superior to patent even for $\mathrm{t}$ in the high region, $[17.9,18]$, due to the deadweight loss from monopoly pricing, but patent is chosen in that region under optimal optional reward.) 